\title{
Are Gram negative bacteria involved in HLA-B27 associated uveitis?
}

The cause of HLA-B27 associated acute anterior uveitis is unknown. Half of the HLA-B27 positive acute anterior uveitis patients, if referred to a rheumatologist, fulfil the criteria for ankylosing spondylitis or reactive arthritis. ${ }^{1}$ It has been suggested that in this group of diseases the HLA-B27 molecule functions as a common pathogenetic pathway. ${ }^{2}$ Ankylosing spondylitis is also a disease with an unknown aetiology. The situation, however, is different for reactive arthritis. Reactive arthritis develops some weeks after a mucosal infection of the gastrointestinal or urogenital tract with Gram negative bacteria or Chlamydia trachomatis. These facts have stimulated research on a pathogenetic role of these bacteria in HLA-B27 associated acute anterior uveitis.

Several interesting results of investigations have recently been reported. Sprenkels et al studied sera from patients with HLA-B27 positive acute anterior uveitis with or without ankylosing spondylitis and from controls consisting of HLA-B27 negative acute anterior uveitis patients and HLA-B27 positive and negative healthy persons. They found that serum levels of both subclasses of IgA were increased in HLA-B27 associated acute anterior uveitis and ankylosing spondylitis. ${ }^{3}$ This might suggest that mucosal infections are involved in the pathogenesis. Fluctuations of the IgA serum levels, however, showed no correlation with the exacerbations of acute anterior uveitis. 4

In a collaborative study with bacteriologists in Turku, Finland, it was found that increased IgA antibody titres to extracts of Klebsiella pneumoniae were detected in the serum of HLA-B27 negative acute anterior uveitis patients but not in sera of HLA-B27 positive acute anterior uveitis patients. ${ }^{4}$ When such sera were tested with an immunofluorescence technique for antibodies to Gram negative bacteria - for example, Klebsiella $\mathrm{K} 43$, the results were negative. 4

About 10 years ago, Ebringer's group in London showed that patients with active ankylosing spondylitis had increased IgA antibodies against Klebsiella pneumoniae. ${ }^{5}$ They recently reproduced this observation by studying the sera from active ankylosing spondylitis patients collected by Sprenkels. However, no increased IgA antibodies to these bacteria were found in the sera from HLA-B27 positive patients having acute anterior uveitis only.

Recently, Sahly et al studied whether the antibodies against Klebsiella capsular polysaccharides are specific for certain serotypes. About $40 \%$ of ankylosing spondylitis patients showed IgG antibodies against the serotypes K26, $\mathrm{K} 36$, and $\mathrm{K} 50$ in increased titres, while such a reaction was not observed in any of the remaining 74 serotypes studied. Only about $10 \%$ of normal controls showed such titres against the three serotypes. ${ }^{6}$ They further reported that the incidence of increased titres against these serotypes may be as high as $85 \%$ in HLA-B27 positive acute anterior uveitis patients. ${ }^{7}$

These findings stimulate further research for a pathogenetic role of these and other Gram negative bacteria. Traces of Gram negative bacteria and Chlamydia have been found in the joints of reactive arthritis patients. Both bacterial antigen and DNA have been demonstrated. On the other hand it is clear that no bacterial infection of the affected joints was present. A similar absence of local infection is probable in the anterior segment of the eye, before or during an acute anterior uveitis exacerbation, when the antigen may be present. The relation between bacterial infections and the HLA-B27 associated diseases is therefore complicated.

Bacteria such as Salmonella and Yersinia can penetrate and proliferate in lymphocytes. Peptides derived from or generated by, these bacteria can be presented by HLA-B27 molecules to cytotoxic T lymphocytes. Such cytotoxic T lymphocytes, which attack and kill the peptide (antigen) presenting cell, have been found in the affected joints of reactive arthritis patients. ${ }^{8}$ It is possible that such a process is responsible for the arthritis.

Whether an analogous activity is present in acute anterior uveitis eyes is, for the moment, a speculation. The problem is even more difficult to explain when one considers that acute anterior uveitis may affect both eyes but mostly one at a time. Nevertheless a possible pathogenetic role of Gram negative bacteria in HLA-B27 associated acute anterior uveitis merits further study.

T E W FELTKAMP

Netherlands Ophthalmic Research Institute and

Central Laboratory of the Blood Transfusion Service,

Amsterdam, the Netherlands

1 Linssen A, Dekker-Saeys AJ, Dandrieu MR, Christiaans BJ, Baarsma GS, Tjoa ST, et al. Possible ankylosing spondylitis in acute anterior uveitis. Br I Rheumatol 1983; 22 (S2): 137-43.

2 Zierhut M, Feltkamp B, Forrester J, Saal J, Dannecker G. Immunology of the eye and the joint. Immunol Today 1994; 15: 294-351.

3 Sprenkels SHD, Hoekzema R, Linssen A, Oosting J, Feltkamp TEW. Serum immunoglobulin levels in HLA-B27 associated acute anterior uveitis and ankylosing spondylitis. Br $¥$ Rheumatol (in press).

4 Sprenkels SHD. IgA, acute anterior uveitis and ankylosing spondylitis. Thesis, University of Amsterdam, 1995.

5 Trull AK, Ebringer R, Panayi GS, Colthorpe D, James DCO, Ebringer A. HLA-B27 and the immune response to enterobacterial antigens in ankylosing spondylitis. Clin Exp Immunol 1984; 55: 74-80.

6 Sahly H, Podschun R, Sass R, Broker B, Kekow J, Gross WL, et al. Serum antibodies to Klebsiella capsular polysaccharides in ankylosing spondylitis. Arthritis Rheum 1994; 37: 754-9.

7 Kekow J, Sahly H, Nolle B, Gross WL, Ullmann U. Detection of antibodies to Klebsiella capsular antigens in ankylosing spondylitis and other rheumatic diseases. Clin Rheumatol 1995; 14: 249-50.

8 Hermann E, Yu DTY, Meyer zum Büschenfelde K-H, Fleischer B. HLA-B27-restricted CD8 T cells derived from synovial fluids of patients with reactive arthritis and ankylosing spondylitis. Lancet 1993; 342: 646-50. 